\title{
Subclinical mastitis in machine milked dairy farms in Punjab: prevalence, distribution of bacteria and current antibiogram
}

\author{
Abdul Q. Mir, B. K. Bansal and D. K. Gupta \\ Department of Veterinary Medicine \\ Guru Angad Dev Veterinary and Animal Sciences University, Ludhiana- 141 004, Punjab, India \\ Corresponding author: B. K. Bansal, email: baljinderbansal@rediffmail.com \\ Received: 21-02-2014, Revised: 24-03-2014, Accepted: 28-03-2014, Published online: 06-05-2014
}

doi: $10.14202 /$ vetworld.2014.291-294

How to cite this article: Mir AQ, Bansal BK and Gupta DK (2014) Subclinical mastitis in machine milked dairy farms in Punjab: prevalence, distribution of bacteria and current antibiogram, Veterinary World 7(5): 291-294.

\begin{abstract}
Aim: Mastitis, a complex disease, even at subclinical stage has a major economic impact on the dairy industry. The disease pattern at machine milking which has recently been introduced in Indian system is to be studied. Therefore the present study was conducted to see the prevalence, distribution and sensitivity pattern of bacteria at subclinical level in machine milked dairy farms in Punjab state.

Materials and Methods: The study involved 10 machine milked dairy cow herds in Ludhiana, Patiala, Moga, Bathinda and Ferozpur districts of Punjab. A total $218 \mathrm{HF} \times$ Sahiwal cross-bred dairy cow in milk were studied. About 872 quarter foremilk samples were collected to observe the prevalence of disease, distribution of udder pathogens and antibiotic sensitivity pattern.

Results: Prevalence of specific subclinical mastitis was $57.80 \%$ and $30.73 \%$ on animal and quarter basis respectively. In specific subclinical mastitis Staphylococci (41.04\%) were the main organisms while in case of latent infections Corynebacteria (36.81\%) were found to be chief isolates. Erythromycin, Enrofloxacin and Gentamicin were found to be most sensitive, and Streptomycin was found to be the least sensitive in vitro antibiotic.
\end{abstract}

Conclusion: Staphylococci were the main organisms in specific subclinical mastitis while Corynebacteria were found to be chief isolates in case of latent infections. Erythromycin, Enrofloxacin and Gentamicin were found to be most sensitive, and Streptomycin was found to be the least sensitive in vitro antibiotic.

Keywords: antibiogram, bacterial distribution, machine milking, prevalence, subclinical mastitis.

\section{Introduction}

Mastitis is the inflammation of mammary gland; it is a complex disease which continues to have a major economic impact on the dairy industry throughout the world $[1,2]$. The losses due to mastitis in USA alone are 1.7 billion dollars [3] while in India the losses are estimated to be about Rs. 7,165 crores [4]. The term mastitis comprises two relatively independent health problems: clinical and subclinical mastitis [5]. Subclinical mastitis is bereft of any obvious manifestation of inflammation and is characterized by having no visible signs either in the udder or in the milk, but the milk production decreases and there is change in milk composition [6]. Subclinical mastitis is 3-40 times more common than clinical mastitis and causes the greatest overall losses in most dairy herds [2].

Mastitis is produced by interplay of the variety of pathogenic agents and bacteria are one of the major etiological agents of the mastitis. The infectious causes of mastitis are vast and at least, 137 infectious causes of bovine mastitis are known to date and in large animals the commonest pathogens are Staphylococcus aureus, Streptococcus agalactiae, other Streptococcus spp. and Coliforms [7]. Mastitis is considered as one of the

Copyright: The authors. This article is an open access article licensed under the terms of the Creative Commons Attribution License (http://creativecommons.org/licenses/by/2.0) which permits unrestricted use, distribution and reproduction in any medium, provided the work is properly cited. major cause of antibiotic use in dairy animals, conventional antibiotic treatment is fast losing relevance due to development of resistance to the antibiotics among the mastitis pathogens, cost consideration and undesirable residues in milk [8]. Identification of mastitis causing pathogen and the results of antibiotic resistance pattern of the isolated bacteria are important prerequisites for implementation of effective control of mastitis.

Therefore the present study was conducted to see the prevalence, distribution and sensitivity pattern of bacteria in machine milked dairy farms.

\section{Materials and Methods}

Ethical approval: Not necessary.

Samples: The present study involved 10 machine milked dairy cow herds in Ludhiana, Patiala, Moga, Bathinda and Ferozpur districts of Punjab. A total 218 $\mathrm{HF} \times$ Sahiwal cross-bred dairy cow in milk were studied. About 872 quarter foremilk samples were collected and subjected to bacteriological examination and California Mastitis Test (CMT) to observe the prevalence of subclinical mastitis on the guidelines of International Dairy Federation (IDF). Quarters were classified into different health groups' viz., healthy, latent, nonspecific and specific mastitis. An animal was considered positive irrespective of number of quarter(s) affected.

Analytical tests: The various analytical procedures 
Table-1: Defining udder health status

\begin{tabular}{lll}
\hline CMT score & \multicolumn{2}{c}{ Microbial pathogen } \\
\cline { 2 - 3 } & Not detected & Detected \\
\hline$<1$ & Healthy & Latent infection \\
$\geq 1$ & Non-specific mastitis & Specific mastitis \\
\hline
\end{tabular}

Specific mastitis means the quarter is bacteriologically positive and having high somatic cell count indicated by positive CMT reaction. Latent infection means only bacteria is present but no cell reaction is present, while non-specific means only cell reaction is there but no bacteria present.

Table-2: Udder health status of dairy cows at various machine milked dairy farms

\begin{tabular}{|c|c|c|c|c|c|c|c|}
\hline \multirow[t]{2}{*}{ Farm ID } & \multirow{2}{*}{$\begin{array}{c}\text { No. of animals } \\
\text { involved }\end{array}$} & \multirow{2}{*}{$\begin{array}{c}\text { No. of quarters } \\
\text { involved }\end{array}$} & \multicolumn{5}{|c|}{ Percent distribution with respect to udder health (quarter wise) } \\
\hline & & & Blind/ Others & Healthy & Latent infections & $\begin{array}{c}\text { Non-Specific } \\
\text { mastitis }\end{array}$ & $\begin{array}{l}\text { Specific } \\
\text { mastitis }\end{array}$ \\
\hline Herd I & 17 & 68 & 0.00 & 47.06 & 16.18 & 19.12 & 17.65 \\
\hline Herd II & 14 & 56 & 0.00 & 48.21 & 14.29 & 23.21 & 14.29 \\
\hline Herd III & 45 & 220 & 7.73 & 25.45 & 12.27 & 17.73 & 36.82 \\
\hline Herd IV & 20 & 80 & 0.00 & 58.75 & 6.25 & 11.25 & 23.75 \\
\hline Herd V & 19 & 76 & 2.63 & 53.95 & 3.95 & 9.21 & 30.26 \\
\hline Herd VI & 12 & 48 & 6.25 & 22.92 & 20.83 & 10.42 & 39.58 \\
\hline Herd VII & 21 & 84 & 0.00 & 39.29 & 34.52 & 1.19 & 25.00 \\
\hline Herd VIII & 23 & 92 & 0.00 & 30.43 & 20.65 & 11.96 & 36.96 \\
\hline Herd IX & 18 & 76 & 1.32 & 22.37 & 28.95 & 19.74 & 27.63 \\
\hline Herd X & 18 & 72 & 1.39 & 30.56 & 13.89 & 12.50 & 41.67 \\
\hline Overall & 218 & 872 & 2.75 & 36.01 & 16.51 & 13.99 & 30.73 \\
\hline
\end{tabular}

Cows positive for specific mastitis $=126 / 218 \times 100=57.80 \%$.

used were as follows:

Isolation and identification of pathogenic bacteria: The isolation and identification of microbial organisms from milk samples was done as per standard microbial procedures of National Mastitis Council [9].

Cultural sensitivity testing: The organisms isolated from quarter foremilk samples were tested for sensitivity to various antimicrobial agents as per method of Ward and Bates [10].

Defining udder health status: The quarter health status was assessed and defined on the basis of bacteriology and SCC estimate (CMT score) of quarter foremilk samples as given in Table-1.

\section{Results and Discussion}

Prevalence of subclinical mastitis: The average prevalence of specific subclinical mastitis at the machine milked dairy farms under study was found to be $57.80 \%$ on animal basis and $30.73 \%$ on quarter basis (Table-2).It is in accordance with the studies [11-13] found the prevalence of subclinical mastitis in cows at machine milked dairy farms as $53.78 \%, 49.29 \%$ and $41.77 \%$, respectively. Similar results were also observed by other studies $[14,15]$ who also found the animal's level prevalence of subclinical mastitis 48.6 to $55.1 \%$ while quarter level prevalence was 34.8 to $42.7 \%$ respectively. However, the other studies [16$18]$, reported a lower prevalence of $29.62 \%, 36.75 \%$ and $14.60 \%$ respectively.

The difference in prevalence of subclinical mastitis in present and earlier studies may be attributed to various factors like climate, season and farm managemental practices such as general hygiene, care of teat injuries, care and working of milking machine, and adoption of various mastitis control measures including teat dipping and dry cow therapy etc. Also the basis of declaring a quarter or animal positive for mastitis, and criteria of classifying organisms into pathogenic or non-pathogenic effects the results to great extent. For example, present study unlike the studies reported above has considered quarters with specific mastitis i.e. positive for CMT as well as bacteriology. Also, in present study quarters infected with Streptococci, Staphylococci (both coagulase positive and negative), Corynebacteria and Bacillus spp. were taken as pathogenic where as many times coagulase negative Staphylococci and Bacillus spp. are taken as non-pathogens [19].

Distribution of organisms: The organisms isolated from specific subclinical mastitis constituted Staphylococci (41.04\%), Corynebacteria (30.60\%), Streptococci (21.27\%), and E. coli and others (7.09\%). However, in case of latent infections Corynebacteria (36.81\%) were found to be chief isolates followed by Staphylococci (27.78\%), Bacillus (20.83\%), Streptococci $(9.72 \%)$ and E. coli and others (4.86\%). The higher prevalence of staphylococcal mastitis has been reported by many workers $[17,14]$ over the years. The higher incidence of Staphylococci indicates unhygienic milking practices as this pathogen is mainly spread during milking via milkers' hands [20].It may also be due to indiscriminate use of antibiotics which have resulted in emergence of more resistant strains (L-form). It is asserted [21] that $S$. aureus is well adapted to survive in the udder and usually establishes a mild subclinical infection of long duration from which it shed in milk facilitating transmission to healthy animals mainly during milking. Also, the organism can survive for longer periods in environment, are widely distributed over the body surface of lactating 
Table-3: Cultural Sensitivity pattern of the bacterial species isolated from cases of specific mastitis.

\begin{tabular}{|c|c|c|c|c|c|c|c|c|c|c|c|}
\hline Organism & No. & G & A & Amoxi & $\mathbf{N}$ & $\mathbf{T}$ & $\mathbf{P}$ & C & $E$ & $\mathbf{S}$ & Enro \\
\hline Staphylococci & 59 & 93.22 & 67.80 & 74.58 & 87.93 & 81.36 & 76.27 & 72.41 & 94.83 & 51.79 & 87.50 \\
\hline Streptococci & 27 & 77.78 & 66.67 & 62.96 & 74.07 & 77.78 & 62.96 & 33.33 & 85.19 & 52.00 & 94.74 \\
\hline Corynebacteria & 31 & 61.29 & 74.19 & 74.19 & 61.29 & 75.61 & 58.06 & 36.00 & 93.55 & 41.38 & 77.27 \\
\hline Others* & 06 & 100 & 33.33 & 50 & 100 & 83.3 & 33.3 & 60 & 75 & 75 & 100 \\
\hline Overall & 123 & 82.11 & 67.48 & 70.73 & 78.69 & 78.95 & 66.67 & 54.78 & 91.80 & 50.86 & 86.96 \\
\hline
\end{tabular}

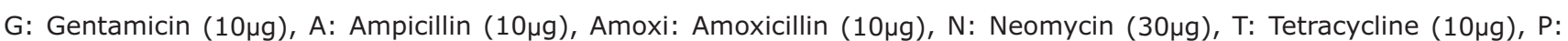

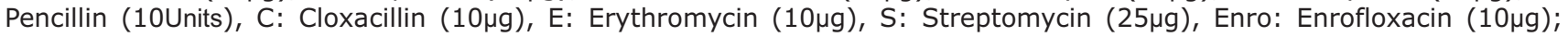
*E. coli. : 01 ; Bacillus spp. : 02; Proteus spp. : 01; Pseudomonas spp.

animals, teat cups of the milking machine and so can easily gain entry into the teat canal.

The one unusual and different finding from that of previous experience at hand milked dairy farms under local conditions is the high share of Corynebacteria, Streptococci and Gram positive aerobic bacilli isolations in machine milked dairy cows. The reason for this difficult to explain, but it is probably related to changes in herd management and consequent bacteriological ecology in the herd environment e.g., it has been observed that suboptimal postmilking teat disinfection may result in a high herd prevalence of these minor pathogens [22]. C. bovis persists with routine application of teat disinfection but is eliminated with dry cow antibiotic therapy [23]. The higher incidence of Streptococci may be due to environmental Streptococci that are considered to become in-habitant in milking machine. A clear linkwas observed between milking machine faults and higher incidence of Streptococcus uberis, an organism regarded as environmental pathogen [24]. She concluded that the increase in $S$. uberis might have been due to teat end damage resulting from the failure of pulsation applied in that environment. Also C. bovis infected quarter's represent a significant risk factor for environmental Streptococcal infections. It has been reported that the presence of $C$. bovis will reduce the likelihood of subsequent infection with $S$. aureus but may increase the risk of infection with $S$. agalactiae and environmental Streptococci [21].

Culture sensitivity pattern: A total of 123 isolates from specific subclinical cases of mastitis were tested for sensitivity to different chemotherapeutic agents (Table-3). Overall, Erythromycin, Enrofloxacin and Gentamicin were found to be highly sensitive, and streptomycin was found to be the least sensitive in vitro antibiotic. Staphylococci were found highly sensitive to Erythromycin, Gentamicin, Neomycin, Enrofloxacin and Tetracycline. Enrofloxacin was the most effective drug against Streptococci followed by erythromycin and tetracycline. Sensitivity pattern of Corynebacteria showed Erythromycin, Enrofloxacin, Tetracycline and Ampicillin as the most effective antibiotics. E. coli and other gram negative bacteria were least sensitive to ampicillin and cloxacillin but were highly sensitive to Enrofloxacin, Gentamicin and Neomycin. The present findings of sensitivity pattern can be compared favourably with the findings of $[25,26,27]$ who also revealed similar sensitivity pattern for different organisms to one or more of these antimicrobial agents. However in another study [12] observed Gentamicin (93.08\%) as the most effective while Pencillin (52.31\%) as the least sensitive antibiotic. Staphylococci were seen to be highly sensitive to Gentamicin while Streptococci and Corynebacteria were highly sensitive to Cephalexin.

The different antibiotic sensitivity pattern observed in the present study may be due to the emergence of newer strains of organisms over the years. Also, it may be due to the differences in the distribution pattern of the organisms. In present work an increased prevalence of environmental organisms like Corynebacteria, Streptococci and gram positive aerobic bacilli was noted; Staphylococci was the only major pathogen isolated in earlier studies. The higher percentage of sensitivity to Erythromycin and Enrofloxacin could be due to their comparatively less use in veterinary practice. On the other hand, lower degree of sensitivity to Penicillin, Cloxacillin, Streptomycin and Ampicillin may be due to their prolonged and injudicious use in veterinary practice under field conditions.

\section{Conclusion}

Staphylococci were the main organisms in specific subclinical mastitis while Corynebacteria were found to be chief isolates in case of latent infections. Erythromycin, Enrofloxacin and Gentamicin were found to be most sensitive, and streptomycin was found to be the least sensitive in vitro antibiotic.

\section{Authors' contributions}

BKB supervised the research. AQM and DKG were involved with sample collection and processing of samples in the laboratory. AQM and BKB participated in draft and revision of the manuscript. All authors read and approved the final manuscript.

\section{Acknowledgements}

The authors sincerely acknowledge the Director of Research, Guru Angad Dev Veterinary and Animal Sciences University and Dean, College of Veterinary Science for providing necessary facilities to carry out the research. The help and cooperation of the farmers are also duly acknowledged. Fund for this research work was provided from the non-plan project on mastitis being funded by Punjab State Government.

\section{Competing interests}

The authors declare that they have no competing interests. 


\section{References}

1. Atasever, S. (2012) Estimation of correlation between somatic cell count and coagulation score of bovine milk. Int. J. Agr. Biol., 14:315-317.

2. Bachaya, H.A., Raza, M.A., Murtaza, S. and Akbar, I.U.R. (2011) Subclinical bovine mastitis in Muzaffar Garh district of Punjab (Pakistan). J. Anim. Pla. Sci., 21:16-19.

3. Sahoo, N.R, Kumar, P., Bhusan, B., Bhattacharya, T.K., Dayal, S. and Sahoo, M. (2012) Lysozyme in livestock: a guide to selection for disease resistance: a review. J. Anim. Sci. Adva., 2: 347-360.

4. Bansal, B. K. and Gupta, D. K. (2009). Economic analysis of Bovine mastitis in India and Punjab-A review. Indian $J$. Dairy Sci., 62:337-345.

5. Olde Riekerink, R. G., Barkema, H. W. Kelton, D. F. and Scholl. D. T. (2008a). Incidence rate of clinical mastitis on Canadian dairy farms. J. Dairy Sci., 91:1366-1377.

6. Guidry, A. J. (2007) Mastitis and the immune system of the mammary gland. Lactation. In: Lauson B L. (ed) 2007. The Iowa State University Press Ames, Iowa, USA. p229-62.

7. Sumathi, B.R., Veeregowda, B.M. and Gomes, A. R. (2008) Prevalence and antibiogram profile of bacterial Isolates from clinical bovine mastitis. Vet. World, 1(8): 237-238

8. Buragohain, J. and Dutta, G. N. (1990) Susceptibility of bovine subclinical mastitis organisms to different antimicrobial agents and treatment. Indian J. Anim. Sci., 60: $550-553$.

9. Hogan, J. S., González, R. N., Harmon, R. J., Nickerson, S. C., Oliver, S. P., Pankey, J. W. and Smith, K. L. (1999) Laboratory handbook on bovine mastitis. Revised edition, National Mastitis Council, Madison, WI. Page no. 1-33.

10. Ward, G. E. and Bates, F. (1983) Improved antimicrobial susceptibility testing. Mod Vet Prac., 64: 795-98.

11. Boro, P. K. (2002) Comparative studies on mastitis and milk at machine milked and hand dairy farms'. M.V.Sc. Thesis, Punjab Agricultural University, Ludhiana.

12. Singh, P. J., Singh, K. B., Jand S. K., Dhingra, P. N. and Nauriyal, D. C. (1994) Incidence, etiolgy and antibiogram of pathogens isolated from subclinical mastitis in machine milked cows. Indian J Dairy Sci., 47: 730-33.

13. Prem Chand, Behra, G. D. and Chakravarty, A. K. (1995) Comparative incidence of mastitis in relation to certain factors in cattle and buffaloes. Indian J. Anim. Sci., 65 (1): $12-14$.

14. Mekibib, B., Furgasa, M., Abunna, F., Megersa, B. and Regassa, A. (2010) Bovine Mastitis: Prevalence, Risk Factors and Major Pathogens in Dairy Farms of Holeta
Town, Central Ethiopia. Vet. World, 3 (9): 397-403.

15. Zeryehun, T., Aya, T. and Bayecha, R. (2013) Study on prevalence, bacterial pathogens and associated risk factors of bovine mastitis in small holder dairy farms in and around Addis Ababa, Ethiopia. J. Anim. Pla. Sci., 23(1):50-55.

16. Saidi, R., Khelef, D. and Kaidi, R. (2013) Bovine mastitis: Prevalence of bacterial pathogens and evaluation of early screening test. Afr. J. Microbiol. Res., 7(9): 777-782.

17. Elbably, M. A., Emeash H.H. and Asmaa, N.M. (2013) Risk Factors Associated with Mastitis Occurrence in Dairy Herds in Benisuef, Egypt. World's Vet. J., 3(1): 5-10.

18. Sobe, I. (1979) Relationship between milking and udder health in a Carinthian dairy. Dissertation Abstracts International, C 39: 414 (Dairy Sci Abstr 43: 1633).

19. Wesen, G. E., Luedecke, L. O. and Forster, T. L. (1968) Relationship between California Mastitis Test reaction and bacteriological analyses of stripping samples. J. Dairy Sci., 51:679-84.

20. Bradley, A. J. (2002) Bovine mastitis an evolving disease. Vet.J., 164: 116-128.

21. Radostitis, O. M., Gay, C. C., Blood, D. C. and Hinchcliff, K. W. (2007) Textbook of the diseases of Cattle, Sheep, Pigs, Goats and Horses. 9th Edn. Bookpower, London. p603-700.

22. Lam, T. J. G.M., Schukken, Y.H., van Vliet, J.H., Grommers, F.J., Tielen, M. J.M. and Brand, A.(1997) Effect of natural infections with minor pathogens on susceptibility to natural infections with major pathogens in the bovine mammary gland. Am. J. Vet. Res., 58:17-22.

23. Brooks, B. W. and Barnum, D. A. (1984) Experimental colonization of the bovine teat duct with Corynebacterium bovis and the effect on milk somatic cell counts. Can. $J$ Comp. Med., 48: 141-45.

24. Lacy-Hulbert, J. (1998) Physical characteristics of the teat canal and the relationship with infection. Proceeding 37th Annual Meeting of the National Mastitis Council. p54-61.

25. Mohanty, N.N., Das, P., Pany, S.S., Sarangi, L.N., Ranabijuli, S. and Panda, H. K. (2013) Isolation and antibiogram of Staphylococcus, Streptococcus and E. coli isolate from clinical and subclinical cases of bovine mastitis, Vet. World, 6(10): 739-743.

26. Suha, A. H. (2012) Prevalence and Bacterial Etiology of Subclinical Mastitis in Dairy Cows in Al Sulaimaniyah District. Kufa J Vet. Med. Sci., 3(1):190-203.

27. Jeykumar, M., Vinodkumar, G., Bashir, B. P. and Krovvidi, S. (2013) Antibiogram of mastitis pathogens in the milk of crossbred cows in Namakkal district, Tamil Nadu, Vet. World, 6(6):354-356. 